\title{
PENERAPAN PERBANDINGAN METODE AHP-TOPSIS DAN ANP-TOPSIS MENGUKUR KINERJA SUMBER DAYA MANUSIA DI GORONTALO
}

\author{
Moh Ramdhan Arif Kaluku', Nikmasari Pakaya ${ }^{2}$ \\ 12aliaskaluku@gmail.com, ${ }^{2}$ nikmasaripakaya@gmail.com \\ ${ }^{1}$ Universitas Negeri Gorontalo, ${ }^{2}$ Universitas Negeri Gorontalo
}

\begin{abstract}
Abstrak
Kinerja merupakan faktor kunci sebuah instansi pemerintahan untuk mengelola SDM. Kinerja SDM pada instansi menunjukkan ukuran kualitas pekerjaan dan digunakan sebagai ukuran untuk mengamati tingkat kinerja. Kinerja yang kurang akan berdampak pada kualitas perkerjaan yang akan dilakukan, terutama pada pelayanan kepada masyarakat. Penelitian ini bertujuan untuk membandingkan hasil yang diperoleh menggunakan metode Analytical Hierarchy Process (AHP)Technique for Order Preference by Similarity to an Ideal Solution (TOPSIS) dengan Analytic Network Process (ANP) TOPSIS dalam pengambilan keputusan untuk mencari nilai yang tertinggi. Pada penelitian ini, metode AHP dan ANP digunakan untuk mencari bobot dari masing-masing kriteria menggunakan parameter dari nilai yang dimasukan untuk memperoleh bobot prioritas, yang nantinya akan digunakan dalam perhitungan TOPSIS. Hasil penelitian menunjukkan bahwa perbandingan kedua metode memiliki perbedaan dalam menghitung kinerja dari SDM di Gorontalo. Dari penelitian diperoleh nilai kinerja tertinggi dengan menggunakan metode AHP-TOPSIS adalah 0,6549 sedangkan nilai tertinggi dengan menggunakan metode ANP-TOPSIS adalah 0,5906.
\end{abstract}

Kata kunci: AHP, ANP, TOPSIS, Kinerja, SDM

\section{Pendahuluan}

Pelayanan dan kinerja yang baik merupakan salah satu faktor utama yang sangat penting yang ada dalam proses bisnis [1]. Demikian halnya dengan pelayanan dan kinerja sumber daya manusia khususnya pegawai di lingkup pemerintahan. Untuk menilai kinerja dari pegawai sangatlah sulit dan subyektif, karena tidak adanya indikator kinerja yang terukur dan obyektif. Sehingga perlu didukung dengan identifikasi Key Performance Indicator (KPI) secara tepat yang berfungsi untuk mengukur kemajuan sesuai dengan sasaran dari organisasi itu untuk menentukan penilai kinerja $[2,1]$.

Di pemerintahan daerah, Pimpinan cenderung sulit untuk melihat dan mengukur knerja dari setiap pegawainya, hal ini disebebkan oleh tidak adanya ukuran baku yang dapat dijadikan patokan dalam mengukur kinerja. Pengukuran kinerja harus dilakukan oleh pelanggan dari instansi tersebut, dalam hal ini adalah masyarakat. Hal ini pula yang menyebabkan tidak adanya data akurat karena masyarakat tidak bisa mengukur kinerja dari aparat pemerintahan tersebut. Kepuasan masyarakat terhadap kinerja pegawai merupakan tolak ukur dari keberhasilan sumber daya manusia yang ada pada setiap instansi pemerintah. Oleh sebab itu perlu dibuatkan sebuah pengukuran kinerja pegawai pemerintahan untuk mendukung pelayanan masyarakat yang maksimal.

AHP merupakan salah satu metode Multi Criteria Decision Making (MCDM) yang sangat baik dalam memodelkan pendapat para ahli dalam sistem pendukung keputusan. Dalam menyusun model, AHP melakukan perbandingan berpasangan variabel-variabel yang menjadi penentu dalam proses pengambilan keputusan [3].

ANP digunakan untuk pengambilan keputusan multi kriteria. ANP merupakan kerangka umum yang digunakan untuk menangani masalah keputusan tanpa membuat asumsi tentang independensi dari kelompok atau elemen [4]. [4] Menjelaskan penggunaan ANP dan TOPSIS dapat digunakan untuk mengoptimalkan strategi dalam pengambilan keputusan. Dengan menggabingkan metode ANP yang memiliki bebrapa kroiteria yang dibandingkan dengan metode TOPSIS untuk menentukan rangking dari penilaian yang dilakukan [5].

Suatu rangkaian aktifitas perusahaan tidak dapat terlaksana tanpa ada dukungan dari sumber daya manusia (SDM) yang kompeten dalam menjalankan aktifitas dari perusahaan itu. SDM yang tidak kompeten menyebabkan kemunduran bagi aktifitas perekonomian perusahaan. Untuk itu kinerja karyawan harus optimal. Key Performance Indicator (KPI) dapat digunakan untuk mengukur pencapaian kinerja dan mengukur penilaian hasil pekerjaan SDM. Dimana KPI menjadi indikator yang digunakan untuk pengukuran kinerja SDM.

Perlu adanya hubungan yang baik antara SDM dan praktek pada pelayanan agar meningkatkan hasil bisnis. Untuk menghasilkan kualitas dan kuantitas yang baik, dilakukan penilaian pada kinerja sumber daya manusia terhadap kinerjanya. Adapun penilaian dilakukan dengan menentukan setiap 
indikator KPI yang ada pada SDM. Diharapkan bahwa hubungan keduanya akan meningkatkan praktek kinerja SDM dan dengan demikian memberikan kesempatan yang lebih besar untuk peningkatan kinerja.

Untuk itu perlu dilakukan pengukuran sumber daya manusia di Gorontalo karena sumber daya manusia merupakan bagian terpenting dalam proses kinerja di dalam organisasi. Sebuah metodologi perbandingan menggunakan metode AHP-TOPSIS dan ANP-TOPSIS digunakan untuk mengukur kinerja dari sumber daya manusia yang ada di Gorontalo. Metode AHP yang berbasis hierarki dan metode ANP yang berbasis jaringan dibandingkan dalam penelitian ini untuk melihat hasil perbandingan dari kedua metode yang digunakan dengan menggunakan metode TOPSIS untuk menentukan peringkat berdasarkan perbandingan berpasangan pada metode AHP dan ANP.

\section{Metode}

\subsection{Analytic Hierarchy Process (AHP)}

AHP merupakan suatu model pendukung keputusan yang dikembangkan oleh Thomas $\mathrm{L}$. Saaty. AHP sendiri merupakan sebuah model pendukung keputusan yang dapat menyelesaikan masalah yang bersifat multi kriteria yang kompleks berdasarkan unsur hierarki sebagai dasar penyusunnya. [6] Hirarki merupakan suatu penggambaran sebuah permasalahan yang kompleks dimana level pertama adalah tujuan, yang diikuti level faktor kriteria, sub kriteria, dan seterusnya hingga ke level terakhir yaitu alternatif. Dengan menggunakan hirarki, masalah dapat digabung ke dalam kelompok-kelompoknya sehingga permasalahan akan tampak lebih terstruktur dan sistematis.

Pada dasarnya, prosedur atau langkah-langkah dalam metode AHP yang digunakan meliputi:

- Mendefinisikan masalah dan menentukan solusi yang diinginkan, lalu menyusun jaringan dari permasalahan yang dihadapi.

- Menentukan prioritas elemen

- Menentukan prioritas elemen dengan membuat perbandingan berpasangan berdasarkan sesuai dengan kriteria yang diberikan dengan mengelompokan dalam komponen yang sama.

- Dalam model AHP, langkah yang harus dilakukan adalah mengetahui suatu tingkat kepentingan terhadap kriteria AHP untuk perbandingan kriteria dalam seluruh sistem. Langkah ini dilakukan melalui matriks perbandingan berpasangan.

- Nilai numerik pada seluruh perbandingan diperoleh dari skala perbandingan 1 sampai 9 yang telah ditetapkan oleh Saaty.

- Menghitung bobot elemen

Dalam pembuatan keputusan, penting untuk mengetahui seberapa baik konsistensi yang ada karena kita tidak menginginkan keputusan berdasarkan pertimbangan dengan konsistensi yang rendah.

- Hitung Consistency Index $(\mathrm{Cl})$ :

$\mathrm{Cl}:(\lambda$ maks-n) / (n-1)

- Hitung Rasio Konsistensi / Consistency Ratio (CR)

$\mathrm{CR}: \mathrm{Cl} / \mathrm{IR}$

\section{Dengan CR : Consistency Ratio \\ $\mathrm{Cl}$ : Consistency Index \\ IR : Indeks Random Consistency}

Bila matriks matriks perbandingan berpasangan (pair-wise comparison) dengan nilai CR lebih kecil dari 0,1 maka ketidakkonsistenan pendapat dari pengambil keputusan masih dapat diterima, jika tidak maka penilaian perlu diulang.

\subsection{Analytic Network Process (ANP)}

ANP merupakan pengembangan dari metode Analytic Hierarchy Process (AHP), AHP sendiri merupakan metode yang lebih banyak memperhitungkan ketergantungan antara unsur-unsur hirarki. Banyak masalah keputusan yang tidak dapat terstruktur menggunakan hirarki karena hierarki lebih mempertimbangkan ketergantungan dengan elemen tingkat yang lebih tinggi dalam hirarki, pada elemen tingkat yang lebih rendah. Sedangkan ANP yang diwakili oleh jaringan, bukan hirarki dapat mengatasi masalah tersebut. ANP adalah cara logis digunakan untuk menangani masalah ketergantungan dari unsur yang lebih tinggi $[4,6]$. 
Model dari metode ANP yaitu berupa jaringan sehingga dapat diketahui saling keterkaitan antara setiap elemen yang ada pada satu kriteria yang sama, ataupun terhadap elemen-elemen yang berbeda kriteria. Langkah menghitung menggunakan metode ANP adalah:

- Pembuatan Supermatrix

Sebelum membuat supermatriks, terlebih dahulu pencarian bobot vektor prioritas menggunakan perbandingan berpasangan sama seperti cara pada metode AHP. Sama halnya seperti AHP, untuk mencari vektor prioritas pada ANP, digunakan tahapan yang sama dengan AHP, yang kemudiann vektor prioritas dapat digunakan jika Consistency Ratio yang diperoleh lebih kecil dari 0,1 , jika lebih besar dari itu maka perlu dilakukan perhitungan kembali terhadap perbandingan berpasangan yang dilakukan.

Supermatriks merupakan hasil vektor prioritas dari perbandingan berpasangan antar cluster, kriteria, dan alternatif. Supermatriks terdiri dari tiga tahap, yaitu:

- Tahap Unweighted Supermatrix

Unweighted Supermatrix diperoleh dari perbandingan berpasangan yang dilakukan sebelumnya, dengan memasukan hasil dari perhitungan vektor prioritas ke dalam kolom yang sesuai dengan selnya.

- Tahap Weighted Supermatrix

Weighted Supermatrix diperoleh dengan cara menormalisasi hasil dari tahap Unweighted Supermatrix sehingga nantinya diperoleh penjumlahan pada kolom yang memiliki jumlah satu.

- $\quad$ Tahap Limmiting Supermatrix

Untuk memperoleh limmiting supermatrix, weighted dikalukan dengan mengalikan Weighted Supermatrix dengan dirinya sendiri sampai memperoleh nilai yang sama pada setiapbaris.

- Menghitung bobot keseluruhan (Global Weight)

Bobot keseluruhan dapat diperoleh dengan mengalikan bobot subkriteria dengan kriteria. Bobot subkriteria diperoleh dari perbandingan berpasangan subkriteria, sedangkan bobot kriteria diperoleh dari perbandingan berpasangan kriteria

\subsection{Technique for Order Preference by Similarity to an Ideal Solution (TOPSIS)}

TOPSIS sendiri merupakan sebuah metode analisis yang tidak hanya mempertimbangkan suatu kondiri dari jarak terdekat tetapi juga mempertimbangkan dari jarak terjauh, sehingga indikator penilaian menjadi lebih objektif [7].

Secara umum prosedur dari metode TOPSIS mengikuti langkah-langkah sebagai berikut $[8,9]$.

- $\quad$ Menentukan TOPSIS membutuhkan ranking kinerja setiap alternatif Ai pada setiap kriteria $\mathrm{Cj}$ yang ternormalisasi.

Hal ini dapat dilihat dari rumus di bawah ini:

$$
\mathrm{rij}=\frac{X_{i j}}{\sqrt{\sum_{i=1}^{m} \mathrm{x}_{\mathrm{jj}}^{2}}}
$$

dengan $\mathrm{i}=1,2, \ldots . \mathrm{m}$; dan $\mathrm{j}=1,2, \mathrm{n}$;

Ai adalah Alternatif dari suatu kegiatan

Cj adalah jenis dari kriteria

- $\quad$ Menghitung matriks keputusan yang ternormalisasi terbobot.

$Y_{i j}=W_{i} r_{i j}$

dengan $\mathrm{i}=1,2, \ldots, \mathrm{m}$ dan $\mathrm{j}=1,2, \ldots, \mathrm{n}$

- $\quad$ Menghitung matriks solusi ideal positif $\mathrm{A}^{+}$dan matriks solusi ideal negatif $\mathrm{A}^{-}$.

$A^{+}=\left(y_{1}^{+}, y_{2}^{+}, \ldots, y_{n}^{+}\right)$;

$A^{-}=\left(y_{1}^{-}, y_{2}^{-}, \ldots, y_{n}^{-}\right)$;

Dimana:

$y_{j}^{+}$adalah Max $y_{i j}$ jika $j$ adalah atribut keuntungan (benefit)

Max $y_{i j}$ jika $j$ adalah atribut biaya (Cost)

$y_{j}^{-}$adalah Min $y_{i j}$ jika $j$ adalah atribut keuntungan (benefit)

Min $y_{i j}$ jika $j$ adalah atribut biaya (Cost).

- Menentukan Menghitung jarak antara nilai setiap alternatif dengan matriks solusi ideal positif dan matrik solusi ideal negatif.

Alternatif untuk solusi ideal positif. 
$D_{i}^{+}=\sqrt{\sum_{j=1}^{m}\left(y_{i}^{+}-y_{i j}\right)^{2}} ; \mathrm{i}=1,2, \ldots, \mathrm{m}$

Alternatif untuk solusi ideal negatif.

$$
D_{i}^{-}=\sqrt{\sum_{j=1}^{m}\left(y_{i j}-y_{i}^{-}\right)^{2}} ; \mathrm{i}=1,2, \ldots, \mathrm{m}
$$

Dimana $\mathrm{D}_{\mathrm{i}}^{+}$adalah jarak terhadap solusi ideal positif untuk alternatif ke-I dan $\mathrm{D}_{\mathrm{i}}^{-}$adalah jarak terhadap solusi ideal negatif.

- $\quad$ Menghitung nilai preferensi untuk setiap alternatif $\left(\mathrm{V}_{\mathrm{i}}\right)$.

$V_{i}=\frac{D_{\bar{i}}^{-}}{D_{i}^{-}+D_{i}^{+}} \quad \mathrm{i}=1,2, \ldots, \mathrm{m}$

Nilai preferensi adalah nilai akhir yang digunakan untuk menentukan peringkat pada semua alternatif yang telah dinilai sebelumnya. Nilai preferensi pada suatu alternatif merupakan perbandingan antara jarak dari solusi ideal negatif dan jumlah jarak terhadap sousi ideal positif. Jika nilai $V_{i}$ merupakan nilai yang paling besar, menunjukkan bahwa alternatif $A_{i}$ telah tepat dipilih.

\section{Hasil dan Pembahasan}

\subsection{Hasil Penelitian}

Penelitian ini menghasilkan sebuah aplikasi web back end sistem. Back end sistem dikelola oleh administrator dalam manajemen kuesioner, manajemen konten, dan pengolahan data dari hasil pengolahan data key performance indicator dan kinerja SDM. Sistem Pengukuran Kinerja dirancang dengan ber-orientasi objek programming. User pada sistem ini terdiri atas dua user yaitu administrator dan responden. Administrator menginput data-data pertanyaan tiap subkriteria yang akan digunakan. Pada sistem ini menggunakan KPI sebagai dasar acuan dalam menentukan kriteria kinerja pada Procurement Section. Dari setiap atribut masing-masing KPI dijadikan pertanyaan untuk responden. Pertanyaan-pertanyaan tersebut menjadi inputan oleh administrator.

Penerapan metode AHP dan ANP untuk menilai kinerja diawali dari menganalisa validitas pengukuran kinerja menggunakan kriteria, yang bersumber dari KPI. Evaluasi dilakukan dengan menilai hubungan pengaruh antara kriteria satu dengan kriteria lainnya. Pada metode AHP dilakukan perbandingan berpasangan antara setiap kriteria dan setiap subkriteria, hasil dari perbandingan berpasangan tersebut diperoleh vektor prioritas yang kemudiann dikalikan antara vektor prioritas pada kriteria dan vektor prioritas pada subkriteria yang kemudian menghasilkan bobot global dari masingmasing subkriteria, seperti yang tampak pada tabel 1.

Tabel 1. Bobot Global AHP

\begin{tabular}{ccc}
\hline KRITERIA & SUBKRITERIA & BOBOT \\
\hline \multirow{2}{*}{0,3889} & 0,7500 & 0,2917 \\
& 0,2500 & 0,0972 \\
0,3889 & 0,8333 & 0,3241 \\
& 0,1667 & 0,0648 \\
0,0687 & 0,2500 & 0,0172 \\
& 0,7500 & 0,0515 \\
0,1535 & 0,1250 & 0,0192 \\
& 0,8750 & 0,1343 \\
\hline
\end{tabular}

Sedangkan pada ANP, perbandingan berpasangan yang dilakukan menggunakan matriks akan digunakan untuk membentuk supermatriks dengan menggunakan nilai dari vektor prioritas yang dihasilkan dari perbandingan berpsangan ada matriks sebelumnya. Hasil analisis mengunakan ANP menghasilkan bobot global yang diperoleh dari limit supermatriks yang nantinya akan digunakan untuk perhitungan TOPSIS yang disajikan dalam bentuk tabel pada tabel 2. 
ILKOM Jurnal IImiah Volume 9 Nomor 2 Agustus 2017

Tabel 2. Limit Supermatriks ANP

\begin{tabular}{ccccccccc}
\hline LS & A1 & A2 & A3 & A4 & A5 & A6 & A7 & A8 \\
\hline A1 & 0,1890 & 0,1890 & 0,1890 & 0,1890 & 0,1890 & 0,1890 & 0,1890 & 0,1890 \\
A2 & 0,0919 & 0,0919 & 0,0919 & 0,0919 & 0,0919 & 0,0919 & 0,0919 & 0,0919 \\
A3 & 0,1310 & 0,1310 & 0,1310 & 0,1310 & 0,1310 & 0,1310 & 0,1310 & 0,1310 \\
A4 & 0,1499 & 0,1499 & 0,1499 & 0,1499 & 0,1499 & 0,1499 & 0,1499 & 0,1499 \\
A5 & 0,0954 & 0,0954 & 0,0954 & 0,0954 & 0,0954 & 0,0954 & 0,0954 & 0,0954 \\
A6 & 0,1395 & 0,1395 & 0,1395 & 0,1395 & 0,1395 & 0,1395 & 0,1395 & 0,1395 \\
A7 & 0,1193 & 0,1193 & 0,1193 & 0,1193 & 0,1193 & 0,1193 & 0,1193 & 0,1193 \\
A8 & 0,0839 & 0,0839 & 0,0839 & 0,0839 & 0,0839 & 0,0839 & 0,0839 & 0,0839 \\
\hline
\end{tabular}

Tabel 1 dan tabel 2 menunjukan nilai dari bobot global dari masing-masing KPI yang dihasilkan dari perhitungan matriks pada AHP dan supermatriks pada ANP. Pada ANP, nilai dari supermatriks menghasilkan nilai pada setiap kolomnya sama. Pada tabel 1 nilai tertinggi adalah subkriteria (A3) dengan nilai 0,3241. Sedangkan pada tabel 2 dari limit supermatriks diatas menunjukan nilai tertinggi adalah subkriteria (A1) dengan nilai 0,1890.

Metode TOPSIS akan digunakan untuk melakukan perangkingan berdasarkan bobot global yang diperoleh dari perhitungan AHP dan ANP. Pada metode TOPSIS, data yang akan digunakan untuk digabungkan dengan metode AHP dan ANP pada perbandingan metode menggunakan data yang sama. Data tersebut diperoleh dari responden yang sebelumnya telah mengisi kuesioner yang dibagikan. Sebelumnya responden mengisi kuesioner untuk menentukan kinerja dari pegawai berdasarkan pertanyaan yang diberikan. Hasil jawaban dari responden dianalisis menggunakan metode TOPSIS. Prosedur dari analisis TOPSIS adalah normalisasi jawaban responden, mengalikan hasil normalisasi dengan bobot normal yang diperoleh dari perhitungan AHP dan ANP sehingga menghasilkan matriks keputusan terbobot, menentukan solusi ideal positif dan solusi ideal negatif berdasarkan nilai terbesar dan terkecil dari setiap subkriteria, menaikan pangkat dari solusi ideal positif dan negatif lalu menjumlahkannya sehingga diperoleh jarak solusi ideal positif dan negatif, serta menentukan nilai preferensi berdasarkan jarak ideal positif dan negatif.

Dari hasil yang diperoleh pada metode AHP-TOPSIS bahwa penilaian terhadap kinerja SDM di Gorontalo memiliki nilai yang berbeda dengan nilai dengan menggunakan ANP TOPSIS. masingmasing pegawai mempunyai nilai akhir berdasarkan penilaian dari responden yang mana dapat menjadi rekomendasi perbaikan kinerja di masa yang akan datang. Hasil akhir dari evaluasi ini dapat menunjukan tingkat kinerja masing-masing pegawai yang telah dirangking. Output dari sistem ini adalah perangkingan SDM yang ditampilkan dalam bentuk tabel dan grafik. Hasil analisis metode AHP-TOPSIS dan ANP-TOPSIS menunjukan nilai preferensi dari setiap pegawai secara keseluruhan yang disajikan dalam bentuk grafik pada gambar 1 dan gambar 2 dan diurutkan dari yang tertinggi sampai yang terendah.

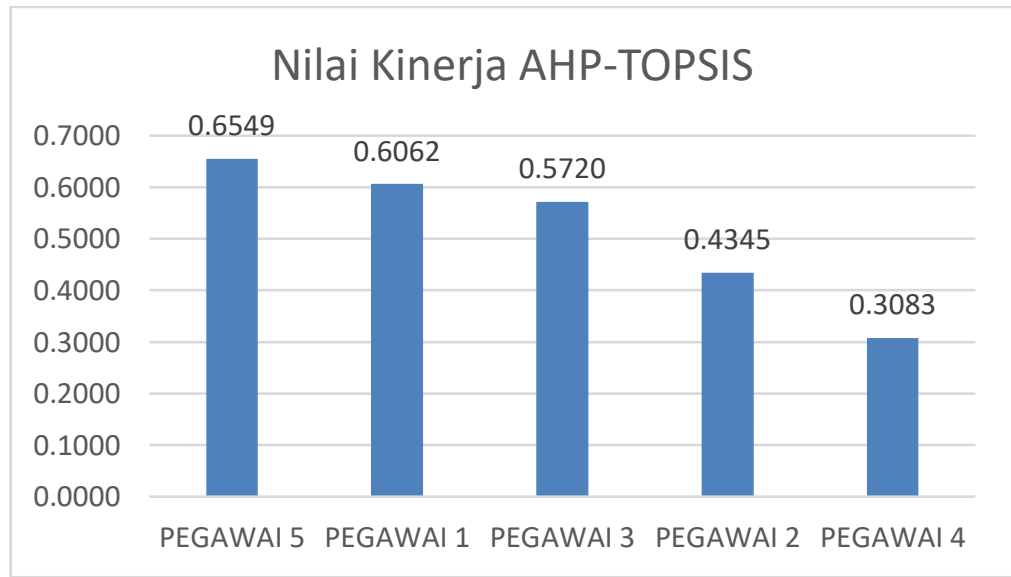

Gambar 1. Hasil Perangkingan AHP-TOPSIS 


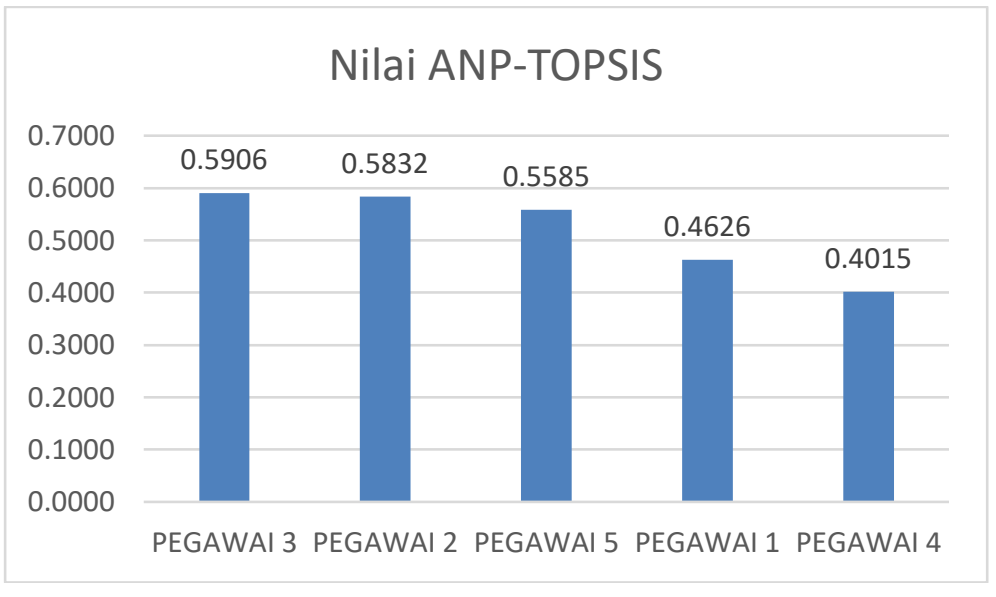

Gambar 2. Hasil Perangkingan ANP-TOPSIS

Dari grafik pada gambar 1 dan gambar 2 jelas terlihat total terbesar sampai terkecil dari lima alternatif kategori yang ada dari SDM yang ada di gorotalo menggunakan metode AHP-TOPSIS dan ANP-TOPSIS. Sehingga diperoleh nilai tertinggi pada metode AHP-TOPSIS adalah pegawai 5 dengan nilai 0,6549 . Sedangkan nilai tertinggi pada metod ANP-TOPSIS adalah pegawai 3 dengan nilai 0,5906. Dari hasil yang diperoleh menunjukan bahwa ada perbedaan hasil yang diperoleh menggunakan metode AHP-TOPSIS dan ANP-TOPSIS. Tetapi dapat dikatakan bahwa hasil ini menunjukan keakuratan data antara kedua perbandingan metode yang digunakan untuk mengukur kinerja dari SDM yang ada di Gorontalo.

\subsection{Pembahasan}

Penilaian terhadap SDM yang ada di gorontalo dilakukan dengan menyebarkan 30 kuesioner ke responden yang dipilih terhadap kinerja dari masing-masing. Hasil yang diperoleh dari pengolahan data dengan menggunakan analisis AHP-TOPSIS dan ANP-TOPSIS menunjukan bahwa kedua perbandingan metode ini dapat digunakan untuk membangun sistem pengukuran kinerja dengan mengacu pada kriteria yang disusun sebelumnya.

Untuk melakukan perhitungan terhadap kinerja SDM, terlebih dahulu dilakukan perbandingan berpasangan menggunakan metode AHP dan ANP. Pada metode AHP diidentifikasi faktor dan kriteria yang mempunyai hubungan hierarki, sedangkan pada metode ANP diidentifikasi faktor atau kriteria yang saling berpengaruh satu sama lainnya dengan melihat saling keterkaitan antara setiap kriteria dengan kriteria lainnya tanpa harus dibatasi oleh kriteria yang lebih tinggi.

Pada tabel 3 berikut dapat dilihat contoh matriks perbandingan berpasangan antar kriteria. Tabel 3 menunjukkan bahwa kriteria KPI1 dan KPI2 merupakan kriteria yang memiliki nilai vektor prioritas yang paling besar yaitu 0,3889 disusul oleh KPI4 serta KPI 3 dengan 0,1535 dan 0,0687.

Tabel 3. Matriks perbandingan berpasangan antar

\begin{tabular}{cccccc}
\hline Kriteria & KPI1 & KPI2 & KPI3 & KPI4 & $\begin{array}{c}\text { Vektor } \\
\text { Priority }\end{array}$ \\
\hline KPI1 & 1 & 1 & 5 & 3 & 0,3889 \\
KPI2 & 1 & 1 & 5 & 3 & 0,3889 \\
KPI3 & 0,2000 & 0,2000 & 1 & $1 / 3$ & 0,0687 \\
KPI4 & 0,3333 & 0,3333 & 3 & 1 & 0,1535 \\
\hline
\end{tabular}

Pada AHP, setelah vektor prioritas atau eigen vector diperoleh dari perbandingan berpasangan antara seluruh kriteria dan seluruh subkriteria, kemudian vektor prioritas tersebut dikalikan yang kemudiann akan menghasilkan bobot global dari setiap subkriteria yang ada, yang nantinya nilai ini akan digunakan untuk perhitungan pada metode TOPSIS.

Sedangkan pada metode ANP, setelah perbandingan berpasangan diperoleh, maka tahap selanjutnya adalah membuat supermatrils. Langkah pertama yaitu membuat supermatriks tak terbobot yang diambil dari vektor prioritas dari perbandingan yang telah dihitung sebelumnya. Setelah itu kemudiann hasil yang diperoleh dinormalisasikan sehingga menjadi supermatriks terbobot yang setiap 
julah setiap nilai pada kolomnya bernilai satu. Dari supermatriks terbobot yang diperoleh, kemudiann supermatriks tersebut dipangkatkan dengan angka terbesar sehingga memperoleh nilai yang setiap nilai barisnya adalah sama. Nilai dari limit supermatris tersebut yang kemudian digunakan menjadi bobot global yang akan digunakan untuk perhitungan pada metode TOPSIS.

Dari perhitungan metode AHP diperoleh bobot global dari masing-masing subkriteria berturutturut adalah 0,$2916 ; 0,0972 ; 0,3241 ; 0,0648 ; 0,0171 ; 0,0515 ; 0,0191$ dan 0,1342 . Sedangkan dari perhitungan ANP diperoleh bobot global yang berturut-turut adalah 0,$1890 ; 0,0918 ; 0,1310 ; 0,1499$; 0,$0954 ; 0,1395 ; 0,1192$ dan 0,0839.

Setelah proses pembobotan menggunakan AHP dan ANP selesai maka tahap selanjutnya adalah perangkingan dengan menggunakan metode TOPSIS. Pengolahan data dengan menggunakan TOPSIS diawali dengan input Tabel Keputusan dari setiap kriteria pada tiap-tiap alternatif yang diperoleh dari hasil kuesioner. Proses metode TOPSIS dilanjutkan dengan pembobotan pada matriks yang telah ternormalisasi. Elemen dari normalisasi matriks keputusan dikalikan dengan bobot kriteria (yang dihitung pada proses AHP dan ANP) sehingga diperoleh normalisasi matriks keputusan terbobot.

Solusi ideal positif dan solusi ideal negatif diperoleh berdasarkan matriks normalisasi terbobot. Elemen dari A+ pada tabel solusi ideal positif dan solusi ideal negatif adalah nilai tertinggi dari masingmasing kolom pada Tabel Normalisasi Matriks Keputusan Terbobot, sedangkan elemen dari $\mathrm{A}^{-}$pada tabel solusi ideal positif dan solusi ideal negatif adalah nilai terendah dari masing-masing kolom pada Tabel Normalisasi Matriks Keputusan Terbobot. Langkah selanjutnya adalah menentukan jarak setiap alternatif terhadap solusi ideal positif dan jarak setiap alternatif terhadap solusi ideal negatif sehingga menghasilkan tabel jarak solusi positif dan negatif.

Nilai preferensi merupakan nilai akhir yang diperoleh dalam menentukan peringkat pada semua alternatif yang ada dari hasil penilaian. Nilai preferensi pada suatu alternatif merupakan perbandingan antara jarak dari solusi ideal negatif dan jumlah jarak terhadap solusi ideal positif.

Tabel 4. Nilai Perangkingan Akhir AHP-TOPSIS

NO RANGKING

\begin{tabular}{lll}
\hline 1 & PEGAWAI 5 & 0,6549 \\
2 & PEGAWAI 1 & 0,6062 \\
3 & PEGAWAI 3 & 0,5720 \\
4 & PEGAWAI 2 & 0,4345 \\
5 & PEGAWAI 4 & 0,3083 \\
\hline
\end{tabular}

Penilaian pada SDM menggunakan metode AHP-TOPSIS menunjukan hasil dari nilai akhir adalah rangking dari setiap alternatif yang diurutkan dari alternatif yang memiliki nilai terbesar sampai alternatif yang memiliki nilai terkecil. Nilai pegawai 5 merupakan nilai terbesar dengan 0,6549 disusul pegawai 1 dengan 0,6062 , pegawai 3 dengan 0,5720 , pegawai 2 dengan 0,4345 dan pegawai 4 dengan 0,3083 . Dengan demikian dapat disimpulkan bahwa kinerja pegawai 5 adalah yang tertinggi dibandingkan kinerja pegawai lainnya menurut dari responden yang menilai.

Tabel 5. Nilai Perangkingan Akhir ANP-TOPSIS

NO RANGKING

\begin{tabular}{lll}
\hline 1 & PEGAWAI 3 & 0,5906 \\
2 & PEGAWAI 2 & 0,5832 \\
3 & PEGAWAI 5 & 0,5585 \\
4 & PEGAWAI 1 & 0,4626 \\
5 & PEGAWAI 4 & 0,4015 \\
\hline
\end{tabular}


Sedangkan penilaian pada SDM menggunakan metode ANP-TOPSIS menunjukan hasil dari nilai akhir adalah rangking dari setiap alternatif yang diurutkan dari alternatif yang memiliki nilai terbesar sampai alternatif yang memiliki nilai terkecil. Nilai pegawai 3 merupakan nilai terbesar dengan 0,5906 disusul pegawai 2 dengan 0,5832, pegawai 5 dengan 0,5585, pegawai 1 dengan 0,44626 dan pegawai 4 dengan 0,4015. Dengan demikian dapat disimpulkan bahwa kinerja pegawai 3 adalah yang tertinggi dibandingkan kinerja pegawai lainnya menurut dari responden yang menilai.

\section{Kesimpulan dan saran \\ 4.1 Kesimpulan}

Berdasarkan hasil penelitian dan pembahasan mengenai penerapan perbandingan metode AHPTOPSIS dan ANP-TOPSIS untuk mengukur kinerja SDM yang ada di gorontalo maka didapat kesimpulan bahwa penerapan perbandingan metode ini dapat mengidentifikasi penilaian terhadap pegawai berdasarkan kategori KPI yang dimasukan. KPI yang digunakan merupakan parameter yang menjadi kriteria untuk mengukur kinerja SDM dengan membandingkan dengan kriteria yang lainnya. Hasil analisis pada studi kasus diperoleh bahwa penggunaan metode ANP lebih baik digunakan daripada metode AHP dalam menganalisis pengukuran kinerja yang ada. Karena walaupun kedua metode memiliki cara yang sama, tetapi metode ANP tidak bergantung pada unsur hierarki yang lebih tinggi yang terdapat pada AHP, karena ANP bersifat jaringan yang tidak tergantung pada unsur yang lebih tinggi. Sehingga tertinggi yang diperoleh dari penggabungan nilai AHP-TOPSIS adalah 0,6549 sedangkan nilai tertinggi ANP-TOPSIS adalah 0,5906.

\subsection{Saran}

Berdasarkan permasalah yang diambil dalam penelitian ini maka disarankan, orang yang memberikan bobot perbandingan bepasangan pada setiap kriteria dan subkriteria pada metode AHP dan ANP adalah orang pimpinan dari instansi agar memperoleh nilai bobot yang tepat.

\section{Daftar Pustaka}

[1] Parmenter, D.2007. Developing, Implementing and Using Winning KPIs. John Wiley \& Sons. New Jersey

[2] Cai, J., Liu, X., Xiao, Z., dan Liu, J. 2009. Improving Supply Chain Performance Management: a Systematic Approach to Analyzing Iterative KPI Accomplishment. Decision Support Systems 46. 512-521.

[3] Calabrese, A, Costa R dan Menichini, T. 2013. Using fuzzy AHP to manage intellectual capital assets : an application to the ICT service industry. Expert Systems with Applications Xxx. Xxx-Xxx

[4] Wu, C.S., Lin, C.T., dan Lee, C. 2010. Optimal Marketing Strategy: A Decision-Making with ANP and TOPSIS, Int. J. Production Economics 127. 190-196.

[5] Shyur, H.J. 2006. Cots Evaluation Using Modified TOPSIS and ANP. Applied Mathematics and Computation 177. 251-259.

[6] Saaty, T.L. 2008. Decision making with the analytic hierarchy process. Int. J. Services Sciences. Vol. 1, No. 1

[7] Zhu, X., Wang, F., Liang, C., Li, J.,dan Sun, X. 2012. Quality credit evaluation based on TOPSIS: Evidence From Air-Conditioning Market In China. Procedia Computer Science 9. 1256 - 1262.

[8] Behzadiana, M., Otaghsara, S.K., Yazdani dan M., Ignatius, J. 2012. A state-of the-art survey of TOPSIS applications Expert Systems with Applications 39 (2012). 13051-13069.

[9] Kusumadewi, S., Hartati, S., Harjoko, A., Wardoyo, R. 2006. Fuzzy Multi Attribute Decision Making (Fuzzy MADM). Graha IImu. Yogyakarta. 